\title{
Turkey's Accession to the European Union in terms of impact on the EU's security and defense policies - potential and drawbacks
}

\author{
A adesão da Turquia à União Europeia em termos de impacto \\ nas políticas de segurança e defesa: potencial e limitações
}

MARIA DO CÉU PINTO*

Rev. Bras. Polít. Int. 53 (1): 89-110 [2010]

\section{Introduction}

At the December 2004 summit in Brussels, the European Union agreed to open access negotiations with Turkey. Turkey finally began talks on joining the European Union in October 2005, more than 40 years after it first began to woo the European bloc: Turkey applied for associate membership of the EEC ${ }^{1}$ back in 1959. On October 3, 2005, the European Union formally initiated accession negotiations with Turkey. Unfortunately, the membership prospects have dimmed since the Brussels decision. ${ }^{2}$ Turkey's EU membership bid has

\footnotetext{
* Professora de Ciência Política e Relações Internacionais na Universidade do Minho, Portugal (mceupinto@ gmail.com).

1 The EEC, European Economic Community (also referred to as the European Community or Common Market), was a European organization that existed between 1958 and 1993, created to bring about economic integration between its members. It was enlarged several times. When the European Union (EU) was created in 1993, the EEC became one of the EU's three pillars.
}

2 Little more than a year later, the EU suspended the talks in a slew of accession dossiers, due to the rift caused by the Cyprus issue. The EU de-coupled the question of Cypriot accession from a settlement on the status of the island's northern third. However, it also underscored the fact that Turkey's own entry would unavoidably be conditional on resolution of its bilateral disputes with Greece. In December 2006, the EU Council voted to suspend eight out of 35 chapters in the access negotiations, freezing the formal progress on chapters directly connected with the bloc's customs union, as Turkey had failed to follow its rules and open its ports and airspace to Greek Cypriots. Turkey had committed under the 2004 Ankara Protocol to opening its ports and airports to Cyprus. These obligations were later incorporated into Turkey's negotiating framework for EU accession, making them an integral part of Ankara's EU bid. Since then, Cyprus has informally blocked several other chapters. Ankara argued it was not prepared to change its position on Cyprus if the EU does not fulfill its commitment to ease the isolation of Turkish Cypriots in the north of the island. Turks were referring to a political pledge made by the EU after Turkish Cypriots supported a UN plan on the unification of the island in 2004, which Greek Cypriots rejected. Greek, not Turkish Cypriots, vetoed the island's unification The Turks say the EU should never have admitted a divided Cyprus after the Greek Cypriots rejection of the UN peace plan. The cooling of political attitudes towards Turkey is also fuelled by public fears of immigration and suspicion towards Islam. The EU also says that Turkey's efforts to bring its laws into line with European standards (the so-caled "Copenhagen criteria") have slowed down. Until recently EU officials talked about possible Turkish membership in 10 to 15 years. The Portuguese European Commission President, José Manuel Barroso, subsequently used the phrase " 15 to 20 years" (BBC, 2006). 
stalled. The disagreement comes against a background of prominent politicians in several EU countries - namely France and Germany - questioning whether the predominantly Muslim country should ever become a member because of its different culture (Fernandes, 2007). An important reason behind the European Council 2004 decision's to elevate Turkey's status to that of candidate country is the EU's evolving security and defence role. EU's policies towards Turkey are shaped by the calculus of the potential benefits of Turkey's inclusion into the EU's Common European Security and Defense Policy (CESDP) and the costs entailed by its exclusion. This motive does not preclude the existence of other rationales, such as the EU's desire to influence Turkey's politics in a positive direction and to resolve the problem over the Cyprus division (Müftüler-Bac, 2000, 489).

With the end of the Cold War, Turkey has a set of new foreign policy options - in the Balkans, Middle East, Caucasus and Black Sea - which are both an asset and a source of concern, either for itself, and for the EU. The demise of the bipolar system radically changed the strategic dynamics in the Middle East, creating a window of opportunity for improved relations and co-operation between Turkey and major actors in this region. The 11 September attacks contributed to further changing the underlying dynamics of international politics in the region. Within some circles in EU countries, there is increasing recognition that, in the post-11 September, post-Iraq war international environment, Turkey is indeed a pivotal country. In the current international setting, Turkey's strategic importance has increased. Turkey today stands at the nexus of several geopolitical areas of critical importance to the EU states. In each of these areas, Turkish cooperation is essential for achieving EU policy goals.

\section{Turkey's assets}

When one reflect on Turkey's contribution to Europe's security, it is important to bear in mind the following facts and figures:

- it shares land borders with countries that are decisive for the security of the Middle East: $500 \mathrm{~km}$ with Iran, $330 \mathrm{~km}$ with Iraq and $820 \mathrm{~km}$ with Syria;

- its large population (72 million) and booming economy make it an important regional power;

- its army is the second largest standing military within NATO, the 9th largest in the world, with over 515,000 active troops and an additional 380,000 reserves (Globalsecurity.org). Membership in NATO and cooperation with the Israeli military has helped it become the most powerful army of Europe, after Russia and UK. It spends 5,3\% of its GDP on defense; in comparison, the US spends $4 \%$, the United Kingdom 2,3\% and France 2,4\% (Gomes, 2007); 
- Turkey has the second-largest land forces in NATO after the USA, ranks $5^{\text {th }}$ in terms of naval forces and operates one of the largest combat aircraft fleets of NATO undergoing a defense modernization program laid out in the final years of the Cold War to develop a force capable of integrated airland battle as part of NATO: it has $10,5 \%$ of NATO's fighter jets, $20 \%$ of cargo planes and 22,5\% of inventory jets (Gasparini, 2004, 25). Ankara can be decisive in closing the glaring capabilities/expectations gap affecting ESDP (European Security and Defense Policy), which will continue to grow in the years to come. The EU's declared goal of being able to deploy 60,000 soldiers - the kind of force that could serve as peacekeepers in hot spots like Bosnia and Kosovo - will require up to 200,000 soldiers because of rotation needs. In 2006, the European allies, with two million soldiers on paper, had trouble fielding peacekeeping forces in Lebanon, mustering barely half of the 15,000 troops called for by United Nations (UN) Security Council Resolution 1701;

- the EU has shortfalls from the previous Headline $\mathrm{Goal}^{3}$ (for instance, gaps related to strategic airlift and sealift) which are still considered to be a limiting factor to the operability of the designated forces, especially in more demanding crisis management operations. With twenty-six C130/C160 transport aircrafts (and ten Airbus A400Ms to be delivered in 2010), the Turkish military can deploy 50,000 troops to conduct joint operations on short notice. With air refueling capability, the Turkish air force is also able to participate in overseas operations. Turkey was among the few significant contributors to the EU operation in the Democratic Republic of the Congo, Operation Artemis, providing the crucial airlift capability that is in short supply in the EU;

- Turkey has shown in the past, namely in the Western Balkans and Afghanistan, that it is a reliable provider of troops to UN-backed international peacekeeping: in Afghanistan in particular, Turkey took command of ISAF for a period of eight months in 2002-2003 and again in February 2005. In practice, Turkey has participated in all EU-led military operations, apart from the operation in the Congo. Last but not least, Turkish contribution in the military-industrial domain could be very useful, and the country's participation - from the start - in the A $400 \mathrm{M}$ programme is a sign of its commitment to the European defense industry (Gomes, 2007).

3 The Helsinki Headline Goal was a military capability target set for 2003 during the December 1999 Helsinki European Council meeting, defined as the autonomous ability to deploy 60,000 troops in 60 days for an operation lasting as long as one year to conduct the "Petersberg Tasks" of humanitarian intervention, peacekeeping, and peacemaking. From the Petersburg task scenarios envisaged, the EU generated the "Helsinki Headline Catalogue" which specifies which capabilities are required in each of 144 capability areas. As the Helsinki Headline Goal became fulfilled, the European Council of June 2004 approved to further develop the EU's military crisis management capability and a new target was set: the "Headline Goal 2010". Capabilities needed for upper level tasks, such as strategic airlift, will take several years to develop and acquire. 


\section{Turkey's participation in EU security}

The added value of Turkey for the EU in the field of security is well-known. One of the useful ways to measure the future utility of Turkey for EU in the field of security is to analyse its present behaviour. On the positive side, one has to mention that the EU and Turkey have already begun to integrate their foreign policies in the pre-accession period. In fact this process has begun with Turkey's association with the EU's nascent security and defense policy (Emerson and Tocci, 2004). Turkey could add - and, in fact, already adds - an important set of diplomatic, cultural and political tools to the EU's external action.

Ankara's active participation in almost all ESDP missions is certainly laudable, and indicates a commitment to a Europe of Defense: Turkey has offered troops, aircraft and command structures to seven EU missions (three military operations and four civilian missions) (Medina-Abellán, 2008, 6). On the negative side, EU-NATO cooperation has long been suffering from Turkey's intransigence concerning ESDP (European Security and Defense Policy) as far as the the application of the Berlin Plus arrangements ${ }^{4}$ is concerned. Angered by the stalemate in EU accession talks, Turkey has blocked the whole EU-NATO strategic partnership and the conducting of military operations involving both organizations. There are several reasons which account for Turkey's attitude: one is the recurrent problem with Cyprus; ${ }^{5}$ the other is that it feels its rights as a third-participating country in ESDP are not sufficient; and thirdly, the sense that it lost a privileged position in the WEU (Western European Union).

Turkey has been an associate member of the Western European Union ${ }^{6}$ since 1992. Associate membership was created to include the European countries that were members of NATO but not of the European Union. The agreement on associate membership allowed for a well-integrated role of associate (and observer) members into the WEU structure, ${ }^{7}$ although without full decision-making rights in WEU.

4 The so-called "Berlin Plus" agreement provides the basis for NATO-EU cooperation in crisis management operations, by allowing the EU to have access to NATO's collective assets and capabilities for EU-led operations, including command arrangements and assistance in operational planning. In effect, they allow the Alliance to support EU-led operations in which NATO as a whole is not engaged.

5 Turkey does not recognize the Greek Cypriot-led government on the divided island of Cyprus and maintains 35,000 troops in the Turkish Republic of Northern Cyprus (KKTC).

6 The Western European Union (WEU) is a European defence and security organisation, established to implement the Treaty of Brussels (1948). Its main feature was the commitment to mutual defence should any of the signatories be the victim of an armed attack in Europe. The organisation was surpassed by the creation of NATO in 1949. On 13 November 2000, WEU Ministers met in Marseille and agreed to begin transferring the organisation's capabilities and functions to the European Union, under its developing Common Foreign and Security Policy (CFSP) and European Security and Defence Policy (ESDP). With the entry into force of the Treaty of Lisbon, later this year, it is expected that WEU members will decide to scrap the organisation altogether.

7 Concerning non-Article 5 activities, the common defense clause. 
In the finalization process of the ESDP, Turkey has been very reluctant to give up the rights that it had acquired within the old Western European Union framework, an organisation which was absorbed into the European Union after 2001. After the December 1998 Saint-Malo Summit, ${ }^{8}$ the EU has started to claim a larger role in terms of defense. This initiative paved the way for the Cologne Summit's decision of June 1999 to merge the WEU and the EU. At the December 1999 Helsinki Summit, the European Council adopted a number of measures to advance the CESDP, stating its "determination to develop an autonomous capacity to take decisions and, where NATO as a whole is not engaged, to launch and conduct EU-led military operations in response to international crisis" (European Council, 1999). The EU members agreed to build, by 2003, a military force of about 50,000-60,000 troops capable of performing and sustaining the full range of Petersberg tasks.

New institutions were created on 1 March 2000 for managing the EU's evolving defense role. In November 2000, the WEU Council of Ministers meeting in Marseilles, took a number of decisions relating to the transfer of its operational role to the European Union. To Turkey's dismay, during the subsequent December 2000 Nice summit, the non-EU members of NATO were totally excluded from the decision-making structures.

In the aftermath of the announcement of the ESDP, Turkey said it was prepared to take part in the ESDP and to provide 6,000 troops for the rapid reaction force. In exchange, it said it wanted to have a voice in decision making and planning processes and be treated as a full-fledged and equal partner on issues that affected its security in the region. It would not acquiesce in the EU's automatic use of NATO capabilities and assets, underlining that it was prepared to consider the use of its veto if the situation required (Kuniholm, 2001).

In October 2002, an agreement was reached concerning the participation of non-EU NATO allies in ESDP. These arrangements were elaborated further in the context of the "NATO-EU Declaration on ESDP", agreed on 16 December 2002, and the Berlin Plus arrangements, adopted on 17 March 2003. They have enabled the use of NATO assets and capabilities by the EU as part of the ESDP operations. Ankara has sought assurances that it will be involved in the planning and decisionmaking in EU crisis management operations, especially those that directly affect its own security interests. This has only become possible under the Ankara agreement of 2001, which stipulates that Turkey automatically participates in EU-led military operations in the event that NATO assets and capabilities are used. The agreement also assured that EU missions would never be directed against an ally (Medina-Abellán, 2008, 3; Haine, 2004, 3). Berlin Plus respected

8 The St. Malo Declaration said that the European Union ought to have the capability for "autonomous action backed up by credible military forces" as part of a common defence policy. It laid the political foundation between France and the Great Britain for the creation of a EU military force, which in turn facilitated the launch of the European Security and Defence Policy. 
Turkey's sensitivities on the exclusion of the Republic of Cyprus (Fernandes, 2008): Cyprus remained outside the area of responsibility of ESDP; a potential force would never be deployed in the Eastern Mediterranean (Medina-Abellán: 2008, 3; Dinela: 2002, 2). In a situation where NATO assets and capabilities are not used - a EU-only operation - Turkey can only participate if the European Council invites it. The EU also accepted Turkey's involvement in the operational planning stage, provide it contributes with forces.

Turkey feels that the EU in recent years violated the Berlin Plus agreement and tried to exclude Turkey from joint operations where NATO's capabilities are used. It feels the elaboration of ESDP, due to the change of the pivotal operational role from NATO to the EU, has amounted to the decline of Turkey's role. Turkey retains its strong interest in European security arrangements and in ensuring itself a continuing and pre-eminent role in NATO. What worries Turkey about the creation of an EU defense force is that it is located in a very volatile zone. The areas near Turkey's borders are those most likely to be the location of EU future crisis management or peacekeeping missions. New missions in defense of common interests are most likely to be performed on the European southern and eastern periphery (in the Balkans or even farther afield, such as Afghanistan and Iraq highlight). Already, most of NATO's current planning scenarios involve contingencies in Turkey's neighborhood, many involving Turkey itself (Lesser, 2000).

The latest crisis between Turkey and NATO occurred during ongoing negotiations to sort out the modalities of an EU administrative mission including EU police force to enable the smooth transition of Kosovo to independence European Union Rule of Law Mission in Kosovo - "EULEX Kosovo" - (Council of the EU, 2008). The EU administrative mission, which has also sought to include a Greek Cypriot police force, took over from the UN mission which has performed that function hitherto, the United Nations Interim Administration Mission in Kosovo. In Kosovo, NATO's military mission, KFOR and EULEX are therefore expected to work together as the military and civilian arms of security. Turkey informed Brussels that it would veto the EU's planned police mission to Kosovo to use NATO capabilities due to the presence of the Greek Cypriots in the mission (Gürcanl1, 2008).

Turkey blocked those plans in protest against a longstanding Cypriot veto of closer defense ties between it and the EU. Cyprus refuses to allow Turkey to join the EU's European Defense Agency (EDA), a body which is meant to streamline EU defense procurement and planning, since it fears that this would give Turkey access to its military secrets. A similar situation occured in 2007, when the EU sent a police mission, including Greek Cypriots, to Afghanistan. Turkey's stance has affected cooperation between NATO's 40,000-strong peace force in Afghanistan and a much smaller EU police mission of around 150 staff.

The most negative consequence of Turkey's insistence that all contacts between EU and NATO take place under Berlin Plus, is the exclusion of the two 
only EU members that are neither NATO members nor members of the Alliance's Partnership for Peace: Cyprus and Malta. Thus, the EU cannot come to terms with the fact that Cyprus and Malta be excluded whenever terrorism, Afghanistan, Kosovo, or Darfur are discussed, which means that NATO and the EU can only meet on these issues informally, or staff-to-staff. Turkey's actions work as a serious break on EU-NATO relations (Medina-Abellán: 2008, 7-8), and, more importantly, they put European, American, but also Afghan and Kosovar lives at risk, since the two organisations are unable to seriously coordinate their actions in providing security to their own people in uniform and to those living in the countries they are trying to stabilize.

Making sure the right security arrangements are in place between ISAF and the EU's police mission in Afghanistan, for example, has been an ordeal and has seriously undermined the international community's reputation in the country. If Turkey's defense establishment were truly committed to EU membership, they would try their best to solve any ambiguities in the country's participation in ESDP through patient negotiation.

Differences related to Turkey's relations with the EU have increasingly spilled over into the NATO arena and affected Turkey's relations with the Alliance. Currently, differences with the EU over Cyprus are hindering the development of NATO-EU cooperation over crisis management and the application of the Berlin Plus arrangements. While not opposed to the expansion of the EU's role in security and defense matters, Turkey does not want the EU initiative to undermine the impact of NATO and the transatlantic link and to erode NATO's deterrence power. The possibility of EU-initiated operations and other activities might weaken NATO's role, reducing Turkey's ability to infuence European security, and adversely affect Turkey's security (Medina-Abellán: 2008, 10).

The EU perception is that Turkey very often uses ESDP as a hostage of the EU membership negotiations: "Turkey believes that its huge military capabilities, its prominent role in European security and its involvement in ESDP are the main backgate of its accession to the EU (...)" (Medina-Abellán: 2008, 10). Maybe it is not a coincidence that Turkey's announcement it was downgrading its participation in ESDP, came immediately after Nicolas Sarkozy's victory in the presidential elections. ${ }^{9}$ Every time Turkey uses its participation in ESDP to pressure the EU and its supporters within the EU, it scuttles its own case. Every time Turkey stands in the way of EU/NATO cooperation on Afghanistan, Kosovo, or the fight against terrorism; every time it reacts to Cyprus' destructive veto of Ankara's participation in the EDA with a counter-productive punishment of the EU as a whole; every time it expresses its skepticism about ESDP generally, Turkey is sacrificing a longterm goal that will endow it with true influence over the future of the Europe of Defense - EU membership -, for a short-term vindication.

9 He expressed his opposition to Turkey's EU membership bid. 
Arguably, Turkey's exclusion could impact Ankara’s long-term commitment to European defense, especially since ensuring Turkish integration into the European security domain would anchor Turkey firmly to the West. That value, however, is not without some qualifications. While Turkey's strategic value is widely accepted within the EU, there are those who see it as an outsider to the European mainstream, condemned to irresolvable difference from its western European neighbors and with frontiers which are a liability.

\section{Turkey's pivotal position}

On the other hand, the evidence is there to suggest that Turkey's stability and its Western alignment are advantageous for the EU since the anticipated threats to the security of the Union originate from the Greater Middle East and the Islamic world at large. The importance of the relations between Turkey and the EU is best appreciated in the context of the new security environment, of the plans for an international order in upheaval and the formation and implementation of a coherent, global EU foreign policy.

The arguments Turkey puts forward to make its case as a foreign and security policy asset to the EU, have been set out by Prime Minister Recep Erdogan. They include:

- Turkey's accession would lead to an extended reach of the European Neighborhood policy. Turkey's neighbors would have a border with the EU;

- Turkey has a geographical location that makes it a hub for regional cooperation;

- Turkey is an increasingly sought-after secure energy-transport hub for oil from the Caspian, Middle East and Russia;

- Turkey is well situated to become a forward base for the EU's security and defense policy, for military logistics and for asserting the EU's presence in the region.

- Turkey has valuable human resources to complement those of the EU for cooperation programmes, ranging from business know-how to language skills (Emerson and Tocci, 2004, 9).

One major argument that links up to this rationale is that, due to its location, Turkey is a strong candidate to become one of the world's most important gas and petroleum terminals in the short term. Through its proactive energy diplomacy, the pipelines in Turkish territory indicate it has become a regional center for energy transportation. Already a vital conduit for sending energy from east to west, Turkey is set to grow in importance as more pipelines come on stream. The most notable is Nabucco, a proposed $€ 7.9$ billion ( $\$ 11.7$ billion) scheme to carry gas across Turkey from Azerbaijan and possibly Turkmenistan, Iran, Iraq and Egypt. This should go some way to reducing Russia's influence over the continent's energy supplies. Moscow now provides Europe with a quarter of its gas needs (Day, 2009). 
Emerson and Tocci have identified ten major theatres of operation in Turkey's vicinity, which one can identify as representing the main common foreign and security concerns of both the EU and Turkey. These consist of the set of Turkey's neighbors, which may be taken as sub-regional groups or major states. The Balkans, the Black Sea, South Caucasus, Central Asia, Russia, Mediterranean, the Middle East, Iraq, Iran, Saudi Arabia and the Gulf. These regions also concern the two other major powers that also have important interests in these regions - Russia and the United States. The authors have concluded that in most cases the interests and policies may be respectively convergent and complementary. If Turkey and the EU share the same vision and similar interests, that would raise the prospects of jointly and more effectively tackling their shared objectives. In that sense, "future Turkish and EU foreign policies could become complementary and mutually reinforcing" (Emerson and Tocci: 2004, 10). Synergies could be materialised in practice, enhancing the capabilities and credibility of the EU as a foreign policy actor and potentially transforming present challenges in future assets and mediation skills.

By setting an example of a modern, secular democratic state and society, capable of coexisting in harmony with the Muslim tradition, Turkey could help ease the tensions and play the role conventionally ascribded as a bridge between the two civilisations. As Emerson and Tocci argue: "democratising Turkey would be the bridgehead of a modern, multi-cultural Europe right up to and alongside the ideological chaos and violence of the neighborhood beyond. Its civilian, military and human resources could be integrated with those of the EU and serve as a spearhead of the EU's soft and not-so-soft power projection into the region" (Emerson and Tocci: 2004, 34). At a time, when the "global war on terror" has created global tension and division, and where 11 September created a backlash experienced by Muslims worldwide, Turkey's relations to the EU take on a broad geopolitical significance.

This security-based argument, by turning the tables on the stereotyped idea that it would be undesirable for the EU to border Iran, Iraq and Syria as well as a turbulent southern Caucasus, sees Turkey's accession as an asset for the EU. Indeed, the harmonization of EU and Turkish foreign policy would be an important qualification for the realisation of the Union's claim that it is a global actor. Turkey's geopolitical location and military capabilities would enhance the EU's standing as a global actor when it becomes a member.

Additionally, Turkey's neighborhood in the eastern Mediterranean, the Balkans, the Middle East and Eurasian regions has become the main source of Europe's security concerns: weapons of mass destruction, terrorism and illegal trafficking of drugs and people. These were identified as priority areas in the European security strategy adopted by the EU in December 2003 (Solana, 2003). Any meaningful European role in the fight against the proliferation of WMD, terrorism and drug trafficking, will have to include Turkey and its important 
diplomatic ties and experience. Secondly, the EU's European Neighborhood policy (European Commission, 2004), which would be extended naturally to the east with Turkey's accession, would become to a large extent a Euro-Turkish Neighborhood policy. Moreover, Turkey offers a number of specific potential assets for helping the EU tackle these concerns, ranging from the concrete realities of location and logistics, through to matters of language and culture, which would facilitate contacts and exchanges with countries in the area.

Turkey's Foreign Minister Ahmet Davutoglu's doctrine that Turkey must not regard itself as a "bridge" country - which sounds somewhat a given fact of History - but as a "center" country - the key player in its immediate area. Some anaysts consider Davutoglu's vision as "neo-Ottomanism" (Taspinar, 2008). Turkish Prime Minister Erdogan's has described Turkey's foreign policy aim as "zero problems" vis-a-vis its neighbors. In the last years, Turkey has opened channels of dialogue with almost all its neighbors (Aydintasbas, 2009; Djavadi, 2009). Turkish foreign policy strategy requires maintaining neutral ties with the various, and some formerly, antagonists. Turkeys's "rising star", to say it with expert Hugh Pope, has led it to strike a balance between friend and foe and even to create a circle of friends through active and unrelenting diplomacy (Pope, 2008). Yet, a reason for the success of AKP's government approach, is that it takes place in the context of a regional power vacuum. The late 2001 intervention of the U.S. and the EU into Afghanistan and the undoing of Iraq, the potential players in the game and their relative balance of power has changed. From this perspective, the new states of the region sought to align themselves, economically, politically and militarily with diverse partners in an environment largely established by the contest of these various powers: Russia, the US, Turkey, Iran, Pakistan, Saudi Arabia and China (Ferguson: 2007, 1).

The traditional Arab powers' influence is waning. The chaotic security situation in Iraq partly explains Turkey's ascendance, bolstered by Ankara's election, in late 2008, to the Security Council as a nonpermanent member.

In effect, Turkey is on its way to resolving its only disputed borders: one is Armenia, the other is Cyprus. The most salient examples are the efforts to restore normal relations with Armenia and with the Iraqi Kurdish. The process of normalising Turkish-Armenian is the most important element of Turkey's new policy towards the Caucasus (EurActiv, 2009). In October, Turkey and Armenia have at last signed a historic accord. Under the agreement, Turkey and Armenia are to establish diplomatic ties and reopen their shared border. This should enable them to make peace and to close the contested matter of the Turkish massacres perpetrated against the Armenians in the second half of the World War I. Hundreds of thousands of Armenians died in 1915, when they were deported en masse from eastern Anatolia by the Ottoman Empire. They were killed by troops or died from starvation and disease. Armenia wants Turkey to recognise the killings as an act of genocide, a situation described by many, in Europe and in the US in 
those terms, but successive Turkish governments have refused to do so. If the move succeeds (it still has to be approved in Parliament, overcoming the likely opposition of Turkish nationalists and the pressures from Azrebaijan), ${ }^{10}$ Turkey could reinforce its prestige as a broker, a regional peacemeaker with a stabilising influence in a volatile region. This move could bolster Turkey's case for EU accession and win back Ankara's reputation of reformist determination, which has faded in the second mandate ${ }^{11}$ of the AKP-led government. The decision will also help Armenia overcome its regional isolation and will open new commercial gateways westward to the economy of landlocked Armenia.

On the negative side, the reality is that Turkey faces a much more diverse set of security threats and challenges: growing Kurdish nationalism and separatism; increasing sectarian violence in Iraq that threatens to spill over and draw in outside powers; an increasingly assertive Iran that may develop nuclear weapons; and a weak, fragmented Lebanon dominated by radical groups with close ties with Syria and Iran. Most of these threats are on Turkey's periphery with the Middle East (Larrabee: 2008, 3). Although Turkey is certainly a potential asset for the EU in the field of security, Europe is not willing to import insecurity with the Turkish accession and demands that Ankara solves a number of pending conflicts. In other words, as long as Turkey does not solve its Kurdish problem; as long as its bilateral relationship with Iraq is not stabilized; as long as it doesn't fully consolidate its relationship with Armenia; and, as long as it doesn't withdraw its troops from Northern Cyprus, EU leaders will be unable to sell Turkish membership as a security-plus to their citizens - quite apart from many other factors where Turkey has made significant inroads accession-wise.

\section{Turkey: drawn into an unstable Middle East neighborhood}

Turkish attention today is focused much more intensely on the Middle East than in the past. As a result, the tension between Turkey's Western identity and its Middle Eastern orientation is likely to grow (Larrabee: 2008, 3). This is where the key challenges to Turkish security are located. Turkey is likely to be drawn more heavily into the Middle East by the Kurdish issue, Iran's nuclear ambitions, and other regional crisis. As a result, the tension between Turkey's Western identity and its Middle Eastern orientation is likely to grow (Larrabee: 2008, vii). Prime Minister Erdogan's government has worked intensively to improve cooperation with Turkey's Middle Eastern neighbors. This year, efforts recently took on

10 Azerbaijan has vehemently protested against the agreement, insisting that the conflict over NagornoKarabakh must be resolved first. Armenia has controlled Nagorno-Karabakh, which lies wholly within Azerbaijan, since a war was fought over the landlocked region between 1988 and 1994 . A ceasefire brokered by Russia has held since 1994. After signing the agrrement, Turkey's Prime Minister Erdogan said that Armenia must withdraw from Nagorno-Karabakh in Azerbaijan to assure his parliament's approval for the agreement, an assertion which may undermine the chance to resolve the crisis.

11 The first was 2002-2007. The AKP won a second mandate in the July 2007 elections with $46.6 \%$ of the vote. 
momentum, with a growing number of high-level visits and cooperation pacts being signed in a range of areas from culture to security, in what some call a process of regional integration similar to the one in Europe. In the past seven years the value of Turkey's exports to the Middle East and north Africa has grown nearly sevenfold, reaching $\$ 31$ billion in 2008 (The Economist, 2009). After all, Prime Minister Tayyip Erdogan party, the AKP (Justice and Development Party) derives from a political Islam movement in Turkey. There is a tendency among some observers to attribute changes in Ankara's foreign policy to AKP's roots in Turkey's Islamist movement. Many analysts fear Turkish relations with the Muslim world may come at the expense of Turkey's Western orientation. They say that, as the AKP loses faith in the EU process, it will lead to a stronger interest and involvement in the Middle East. Howeer, one must take into account the structural changes in international politics that coincide roughly with the two wars against Iraq and the changes in the regional power balance (Cook: 2007, 28).

Currently, the most pressing issue on Turkey's agenda is its relationship with Iraq. Turkey has its own interests in the evolving situation in Iraq and is watching developments there with great concern. Ankara thinks the situation has the potential to be highly destabilising if it deteriorates further. Civil war or a fragmented Iraq, and the possible emergence of an independent Kurdistan in the northwest, would impact strongly on Turkish foreign policy, especially if Ankara feels compelled to intervene there to contain the fallout.

The most important external challenge Turkey faces today is Kurdish nationalism. In the aftermath of the invasion, Iraq has degenerated into sectarian violence and the Kurdish push for autonomy - and eventual independence - has been strengthened. As a result, Turkey today confronts the prospect that an independent Kurdish state will emerge on its southeastern border, which could strengthen separatist pressures among Turkey's own Kurdish population. Since 2004, Turkey has faced an escalation of PKK-led ${ }^{12}$ separatist violence. Turkey is also concerned about the intention of the Kurdistan Regional Government in Northern Iraq to incorporate the city of Kirkuk ${ }^{13}$ and adjacent areas under its

12 The PKK, the Kurdistan Workers' Party is a separatist militant organization. The group was founded in the late 1970 s and it aims to create an independent, Kurdish state in Turkey. Kurdistan is a widgeographical region that comprises parts of southeastern Turkey, northeastern Iraq, northeastern Syria and northwestern Iran, where Kurds are the majority. The PKK is listed as a terrorist organization internationally by a number of states and organizations, including the United States, United Nations, NATO and the European Union.

13 Kirkuk is a city in northeastern Iraq. It is the centre of the northern Iraqi petroleum industry. It is an historically and ethnically mixed city populated by mostly Kurds, Assyrians, Turkmen and Arabs. Kirkuk's citizens - specifically its Kurds and Turkomen - were victims of an ethnic cleansing, expulsion, and 'Arabization' campaign carried out by the Baathist regime of Saddam Hussein during three and a half decades of absolute rule. The status of Kirkuk is a critical issue for Iraq's post-Saddam constitutional democracy. The process for resolving this status is set in Article 140 of the Iraq Constitution: it calls for the normalization of Kirkuk's status, including the proper restoration of its pre-1968 boundaries, to be followed by a referendum on its unification with the Kurdistan Regional Government (KRG). The Kirkuk referendum is the Kirkuk part of a plebiscite that will decide whether the Kurdish regions within Iraqi governorates will become part of the Iraqi Kurdistan region. The referendum was initially planned for 15 November 2007, but has been delayed. 
control. Turkey fears that Kurdish control of Kirkuk's oil wealth would enable the Kurds to create an independent state (Larrabee: 2008, 7-11). ${ }^{14}$ Turkey wants Iraq to remain whole, but it realizes that if tensions in Iraq devolve into all-out violence and the country breaks apart, Turkey would be better off with a friendly partner in Iraq's energy-rich north. In October, Turkey and Iraq took a giant step forward to boost ties, signing more than 40 agreements. The deals were signed at a meeting of the key government ministers of the two countries under the HighLevel Strategic Cooperation Council (Kene, 2009).

Recently, the Turkish government, has undertaken a number of potentially significant measures in a search for a solution to the country's long-standing "Kurdish problem" (Ramonet, 2004) and to cement Turkey's expanding ties with the Kurdish administration in northern Iraq. For decades, Kurdish nationalists have demanded that Turkey end forceful assimilations and denial of even basic rights of Kurds and recognise their legitimate cultural rights by creating a dual educational system where classes are held in both Turkish and Kurdish. ${ }^{15}$ The AKP aims to resolve the question by granting some basic individual and cultural rights to the millions of Kurds. The AK has reversed decades of official policy by trying to meet the demands of Turkey's large Kurdish minority (some 14 million in a total population of 72 million).

The initiative called "Kurdish opening" was a welcoming development: it envisaged bringing members of the PKK back to Turkey from the organization's bases in Iraq and cells in Europe through an unofficial amnesty. The return of the 12,000 refugees in the UN-run camp at Makhmour, in northern Iraq, is part of the Turkish government's plan to broaden freedoms for its Kurdish community and secure an end to the 25 -year violence by separatist Kurdish rebels, inside and on Turkey's borders. It is also a calculated political move to cement Turkey's expanding ties with the Kurdish administration in northern Iraq. Iraq's Kurds, despite age-old tensions with Turkey, have also warmed their relations as trade has boomed and the looming departure of the US troops, the Kurds' protectors, raises the spectre of isolation. Unfortunately, the government has since backed down, calling off its plan to bring more PKK members back to Turkey, when a group of them, whom the Turkish government had allowed into the country from Iraq, delivered fiery speeches in support of the terrorist group (Cagaptay, 2009a).

Turkey is opposed to isolating Iran and Syria or overthrowing the regimes in either country. Rather, Ankara favors policies aimed at engaging Iran and Syria and to encourage the United States to open dialogues with both countries.

\footnotetext{
14 Larrabee's study.

15 The Kurdish language had long been banned in Turkey, and in 1967 the government officially outlawed publishing books and other types of printed material in Kurdish. It also made it illegal to record, sing or otherwise disseminate Kurdish songs and music. It was only during the presidency of Turgut Ozal in the early 1990s that the Turkish government acknowledged the Kurdish language as an important component of the country's Kurdish identity.
} 
Erdogan's government is strongly opposed to a military strike against Tehran, which it believes could further destabilise the region. Turkey's interest in good relations with Iran and Syria is in line with the European positions (Larrabee: 2008, 4). However, Turkey's outreaching should not be seen as undermining attempts to pressure Iran or as giving cover to Syria's maverick behavior. During Prime Minister Erdogan's visit to Tehran, he stressed Iran's right to nuclear power for civil purposes, pointedly congratulated Iran's president, Mahmoud Ahmadinejad, after his disputed election win in June (Uslu, 2009). He further said that countries opposed to Iran's atomic program should give up their own nuclear weapons and defines as 'arrogant' the sanctions imposed on Tehran. These declarations threaten to stir fresh tensions between Turkey and the EU, after Turkish leaders provoked a crisis in relations with Israel by banning it from participating in joint military exercises. Turkey and Syria, two former enemies, have also mended relations in late 2009 (Haddad, 2009). Relations have improved swiftly after decades of mistrust based on Ankara's accusations that Damascus supported Turkey's banned Kurdistan Workers' Party. Turkey boosted its ties with Syria with a newly formed cooperation council. The new cooperation agenda called for a series of meetings between respective ministers and the signing of diplomatic and economic agreements (Al Jazeera, 2009).

Rather than seeing Turkey's ties to Tehran and Damascus as a problem, Europe should view them as an asset. The EU might spur Turkey to find a way to play a bridge- building role between Iran and the international community in order to end Tehran's nuclear ambitions. As Turkey increases its relationships with states like Iran and Syria, which the United States and the EU, to a lesser extent, regard as destabilizing elements in the region, Ankara's value to the EU may increase further it it becomes a player in European-Middle Eastern rapprochement. In fact, supporters of the AKP's new foreign policy argue that "Turkey is finally finding its voice in international politics" (Abramowitz e Barkey: 2009, 5). It should go without saying that Turkish assertion should not undermine Turkey's EU membership bid, nor jeopardize its credibility and the positive role it can play in the broader region.

One relevant aspect, involves Turkey's relationship with Israel. Since 1993, Turkey has been engaged in extensive cooperation with Israel, formalised in a range of agreements stretching from cultural to military matters. The initiation of the Middle East peace process and the signing of the Oslo Agreement in 1993 created a conducive environment for the enhancement of relations between the two countries. In 1996, the signing of the defense and co-operation agreement signalled the emergence of new strategic co-operation. The agreements on military cooperation brought Turkey and Israel together as true security partners in the Middle East.

While relations in military co-operation, trade, and tourism flourished, this new partnership proved to be mutually beneficial. In 2007 , in the wake of the 
Israeli Prime Minister, Ehud Olmert's visit to Turkey, Ankara started mediating the Israeli-Syrian indirect peace talks. The 2008 Gaza offensive led to the disruption of indirect peace talks between Israel and Syria. The offensive - which killed hundreds of civilians besides Hamas members - and ongoing turmoil in the Palestinian enclave contributed to Turkey's decision to freeze relations with Israel.

However, the escalating tensions in the Arab-Israeli conflict and the crisis in Lebanon during the summer of 2006 have adversely affected the relations, by negatively influencing Turkish public opinion towards Israel. Under the current AKP government, the dynamics have started to change somewhat. Ties have frayed as Turkish public opinion, which now counts for more, has turned increasingly hostile to Israel. The bloodshed in Gaza outraged many Turks, who praised Erdogan when he stormed out of a debate with Israel's president, Shimon Peres, stormed out of the world economic forum in Davos, Switzerland after a heated debate with Shimon Peres on Gaza, earlier this year. In February, Turkey hosted leaders of the militant Palestinian Islamist group Hamas, a visit that outraged Israel and the United States and dismayed the EU and some Turkish political circles. In an interview with The Washington Post, Erdogan called for recognition of Hamas which won a landslide victory in Palestinian elections in 2006. He said isolating Hamas is the reason for the ongoing tensions in the region (PressTV, 2009). In early October, Turkey disinvited Israel from Anatolian Eagle, an annual Turkish air force exercise that it had held with Israel, NATO, and the United States since the mid-1990s. A day after it dismissed Israel, Turkey invited Syria to joint military exercises and announced the creation of a Strategic Cooperation Council with Damascus. As Cagaptay has pointed out, "Turkish-Israeli ties - long a model for how a Muslim country can pursue a rational, cooperative relationship with the Jewish state - will continue to unravel" (Cagaptay, 2009).

Another important development is that recently Turkey has begun playing a new role in the Middle East: that of mediator. Turkey was one of the countries, together with Qatar, that mediated an agreement between the U.S.-backed ruling coalition and the Hezbollah-led opposition alliance in Lebanon's presidential election process. It is mediating Iraq and Syria's recent dispute. Iraq and Syria are entangled in a diplomatic dispute over demands that Damascus extradite two suspects wanted in suicide attacks in Baghdad. Iraq says Syria has been used as a launching pad for violence in Iraq (AP, 2009).

Drawing on its growing closeness to Iran, Syria and Iraq, Turkey is working to position itself as a key regional mediator in the Middle East. Turkey's bid might be part of a larger plan to improve its relations with neighbors and take full advantage of its location and historical ties. Ankara is poising to play a larger role than it has in previous decades. As the relations between Turkey and the European Union follow an uneven course, Turkish foreign policy trends have demonstrated a strategic shift toward the Middle East. 


\section{Turkey: poised between East and West}

Turkish membership of the European Union has a variety of political implications. Turkey's contribution to the EU's security and defense policy would bring numerous benefits through Turkey's military capabilities and the positive role it could play in its neighboring vicinity: the Balkans, the Caucasus, the Caspian area and the Middle East. Turkey's military capabilities are vital for operations in the expanded European security area. Its ability to affect EU operations through its vote in NATO's Atlantic Council cannot be underestimated.

Turkey's strategic geographical location, its large Muslim population and assets make it an important powerful player and will add to the already complex set of alliances and foreign policy combinations that are possible. Turkey's entry to the EU will shift the Union's borders to the southeast and increase the Union's range of interests in these complex regions. The main immediate threats to European security come from the Middle East, Afghanistan and Pakistan, areas adjacent to Turkey. The EU's fight against the proliferation of WMD, terrorism and drug trafficking, will have to include Turkey diplomatic ties and experience with those problems.

With the Turkish neighborhood extending deeper into the southeastern periphery, the EU and Turkey may have convergent interests in some of the neighboring regions, but there are equally a number of areas where interests may part. Overall, one may argue EU and Turkey are foreign policy actors with several affinities, as far as the Middle East agenda is concerned. The Turkish Foreign Minister has argued that Turkish foreign policy had been unbalanced, with an overemphasis on ties with Western Europe and the United States to the neglect of Turkey's interests with other countries, particularly in the Middle East (Taspinar: 2008, 14). This diversification, as Larrabee points out, "is on the whole healthy, and should be no cause for alarm. On the contrary, Ankara's strong ties to the Middle East can be an asset for the West as Turkey can serve as a bridge to the Middle East. But to play this role Turkey needs to maintain a firm anchor to the West - and above all to Europe" (Larrabee, 2009).

Turkey is working to position itself as a key regional partner, mediator and interlocutor in the Middle East and is in line with the AKP's "neo-Ottomanism" philosophy. Turkey's bid is part of a larger plan to improve its relations with neighbours and take full advantage of its location and historical ties. Ankara is poising to play a larger role than it has in previous decades. Turkey's policy focus is somewhat more multi-regional in focus than before (Ferguson: 2007, 3). It is already now playing a new role as mediator and powerbroker in the Middle East, namely in Lebanon, Israel, Syria and Iraq. Turkey's multidimensional foreign policy (Abramowitz and Barkey: 2009, 5), does not preclude the maintenance of the EU and the United States as key partners in Turkey's new Eurasian roles 
(Ferguson: 2007, 3) Given its location, Turkey has strong regional interests, but they not translate automatically into a pretension to be a major player on all its areas of vicinity. It has turned its face toward the Middle East and Arab countries, although, as of yet, there is not a clear vision of Turkey's real influence in the region.

As a close neighbor with historical ties to the region, Turkey can act as a useful interlocutor, especially at a time when U.S. ties to Iran and Syria are strained. Rather than a "bridge" or a "buffer zone", some analysts suggest that Turkey can and would act to some extent as an interpreter or translator for the EU with the Middle East, in the sense that it could advocate EU's interests in the region. Turkey could play a leading role in resolving political conflicts; boosting economic cooperation and investment within the region; and supporting political, economic, and social reforms. As the most democratic Muslim country in the Middle East, one with rich experience dealing with and adapting to Western institutions, Turkey is the best-suited Middle Eastern country to lead the effort to advance regional stability and development. Advocates of of Turkey's membership in the EU say the EU and the international community should support Turkey in this role. Turkey's growing political ties with Iran are an asset for the EU as it seeks to expand its influence and to find a diplomatic solution to the international stand-off over Iran's nuclear program. The access of AKP leaders to Iranian leaders, should strengthen the arguments that Turkey is in a position to persuade the Iranian leaders not to defy the demands of the International Atomic Energy Agency and risk international sanctions and reproval. The improvements in the Turkey-Syria relationship takes place as the EU is negotiating an Association Agreement with Damascus and amidst a great interest the Syrians have demonstrated in getting closer to the EU. Turkey and the EU should work together closely to draw Syria into a wider net of international cooperation and reciprocal obligations. Damascus sorely needs to break its diplomatic isolation. The EU can offer trade, know-how, technology, and investment, all of which the Syrian enconomy is in desperate need. Turkey's relatively constructive relationship with Israel, although undergoing a thawing, could benefit the EU. As far as the Israeli-Palestinian conflict is concerned, Brussels and Ankara share the same objectives - a similar vision of a two-state solution - and could complement their relative diplomatic clout to intervene with the participants. The EU and Turkey could work together fruitfully on Israel-Palestine trying to break the deadlock in the peace process (Everts: 2004, 5-7).

During President Obama's visit to Ankara, he signaled Washington's support for Turkey's entry in the EU and for Turkey's role in the Middle East. Turkey's growing influence in the Middle East can be a sure way of enhancing its asset value for the EU and facilitating Turkey's European bid.

Turkey could indeed perform that role, but to an extent that should not be overestimated. Turkish efforts over the last two years to mediate between Syria 
and Israel, the Lebanese groups, and, more recently, Palestinian organizations -, as well as its offer to mediate between Iran and the United States on the nuclear issue - have met with limited success so far. The AKP's more recent clumsy foreign policy initiatives shows it apparently wants to boost ties with the Islamic world even at the risk of undermining Ankara's traditional alliances. The freezing of relations with Israel, the championing of Iranian-backed Hamas, a militant group shunned by Israel and the West, are examples of moves that could damage Turkey's international standing and its EU candidacy. Many analysts also see in Ankara's hectic foreign policy bridge-building, the signs that the AKP wants to remould Turkey's foreign policy along more Islamist lines. The AKP's rise to power is the reflection of the revival of Islamic feeling in Turkey after decades of enforced secularism, a trend which has swept the neighboring Muslim region. Skeptics usually focus on AKP's Muslim political background and tend to see a hidden Islamic agenda behind openings to the Arab world.

On the other hand, it must be said that Turkey's mediating role will always be limited by Turkey's inability to legitimately represent the Arab world. The Turkish Republic is the culmination of a very particular historical development and it is not clear that Turkish accession to the EU would be seen as an example to follow by other Islamic countries (especially in the Arab world), which cope differently with the twin challenges of democratic change and assimilating the role of Islam in society. The strict secular nature of the Turkish Republic's political system, puts it in a special position as far as its Muslim neighbors are concerned. Moreover, unlike any other country in the region, Turkey has a long-standing relation with the West: institutionally through NATO and to a certain extent, already wih the EU, apart from a special link to the US and privileged relationships with other states.

Turkish officials have been careful to explain that their renewed interest in the Muslim East does not mean a chill towards the West. They argue that such an Islamic agenda simply does not exist, mainly on the grounds that the AKP is the most pro-European Union political party on the Turkish scene. Yet, is cannot be ruled out that such an equidistance could change if Turkey's prospects for joining the EU die. It is obvious that Turkey considers herself as a European state and aims to be an equal and a major state within the EU (Ferguson: 2007, 3). For this reason, the basic and stable characteristic of Turkish foreign policy is its tendency towards the West, as demonstrated by the early alliance with NATO and the associate membership in the European Economic Community back in the 1950s. What the trends analysed in this article portend is that Ankara is now poised to embrace the West as much as the Islamic world. That means that Turkey will pursue its EU endeavour, without giving up her intentions to play a more independent and self-interested Middle Eastern role. 


\section{Bibliography}

\section{Primary sources}

Council of the European Union. 2008. "Kosovo: Council Establishes an EU Rule of Law Mission, Appoinst an EU Special Representantive". Brussels, 16 February. Publicado em: [at http://www.eupt-kosovo.eu/new/home/eng/st06613.en08.pdf]. Disponibilidade: 18/03/2009.

European Commission. European Neighbourhood Policy - Strategy Paper, Brussels, May 2004.

“Helsinki European Council 10 and 11 December 1999 - Presidency Conclusions". Publicado em: [http://www.europarl.europa.eu/summits/hel1_en.htm]. Disponibilidade: 16/10/2009.

SOLANA, Javier. 2003. A Secure Europe in a Better World, European Security Strategy, European Commission, Brussels, 11-12 December. Publicado em: [http://ue.eu.int/pressdata/EN/ reports/78367.pdf]. Disponibilidade: 19/03/2009.

\section{Books}

FERNANDES, José Pedro Teixeira. A Turquia: Metamorfoses de Identidade. Lisboa: Imprensa de Ciências Sociais do Instituto de Ciências Sociais, 2005.

FERNANDES, José Pedro Teixeira. A Questão de Chipre-Implicaçôes para a União Europeia e a Adesão da Turquia. Coimbra: Almedina, 2008.

\section{Research Reports}

COOK, Steven A. Islamist Political Power in Turkey: Challenges for Brussels and Washington, SWP-Berlin, project The Challenge of Islamists for EU and US Policies. November 2007. Publicado em: [http://www.cfr.org/publication/15236/islamist_political_power_in_turkey. html]. Disponibilidade: 09/11/2009.

DINELLA, Harry. The Growing Influence of Brussels on Turkish Policy. Woodrow Wilson International Center Documents and Papers. February 2002.

EVERTS, Steven. As Asset But Not a Model: Turkey, the EU and the Wider Middle East. Centre for European Reform Essays, London. October 2004.

GASPARINI, Giovanni, Ed. Turkey and European Security. IAI-TESEV Report IAI Quaderni English Series, No 8, February 2007.

EMERSON, Michael and TOCCI, Nathalie. Turkey as a Bridgehead and Spearhead Integrating EU and Turkish Foreign Policy. EU-Turkey Working Papers. Centre for European Policy Studies, No 1, August 2004.

HAINE, Jean-Yves. ESDP: An Overview. EU Institute for Security Studies. Paris, 2004.

LARRABEE, F. Stephen. Turkey as a U.S. Security Partner. Santa Monica, CA: RAND Project Air Force, 2008.

MEDINA-ABELLAN, Miguel. Turkey, the European Security and Defence Policy, and Accession Negotiations. SInAN - Strengthening and Integrating Academic Networks, Working Paper-1, Center for European Studies, Middle East Technical University, 24 April 2009. 
TASPINAR, Ömer. Turkey's Middle East Policies - Between Neo-Ottomanism and Kemalism. Carnegie Papers. NY, Carnegie Endowment for International Peace, 2008. Publicado em: [http://www.carnegieendowment.org/files/cmec10_taspinar_final.pdf]. Disponibilidade: 07/11/2009.

\section{Articles}

CAGAPTAY, Soner. Is Turkey Leaving the West? An Islamist Foreign Policy Puts Ankara at Odds With Its Former Allies. Foreign Affairs, 26 October 2009.

LESSER, Ian O. Turkey in a Changing Security Environment. Journal of International Affairs, October 2000.

KUNIHOLM, Bruce. Turkey's Accession to the European Union: Differences in European and US Attitudes, and Challenges for Turkey. Turkish Studies, Vol. 2, No 1, Spring 2001.

MÜFTÜLER-BAC, Meltem. Turkey's Role in the EU's Security and Foreign Policies. Security Dialogue, Vol. 31, No 4, December 2000.

ABRAMOWITZ, Morton and BARKEY, Henry J. Turkey's Transformers. Foreign Affairs. November/December 2009.

\section{Electronic documents}

AL JAZEERA. 2009. Turkey and Syria Forge Closer Ties. 14 October. Publicado em: [http:// english.aljazeera.net/news/middleeast/2009/10/20091013947216247.html]. Disponibilidade: 10/11/2009.

AYDINTASBAS, Asli. 2009. Looking to the East. New York Times. 20 February. Publicado em: [http://www.nytimes.com/2009/02/20/opinion/20iht-edasli.4.20336561.html]. Disponibilidade: 06/11/2009.

BBC. Turkey's Entry Talks. 2006. 11 December. Publicado em: [http://news.bbc.co.uk/2/ hi/europe/4107919.stm]. Disponibilidade: 10/11/2009.

CAGAPTAY, Soner. 2009. "Kurdish Opening” Closed Shut. Foreign Policy. 28 October. Publicado em: [http://www.foreignpolicy.com/articles/2009/10/28/kurdish_opening_ closed_shut]. Disponibilidade: 06/11/2009.

DAY, Matthew. 2009. Turkey Deal Clears Way for Pipeline. News.Scotsman.com. 14 July. Publicado em: [http://news.scotsman.com/world/Turkey-deal-clears-way-for.5455298.jp]. Disponibilidade: 08/11/2009.

DJAVADI, Abbas. 2009. 'Turkey's Kissinger' Leads Foreign-Policy Balancing Act. Radio Free Europe/Radio Liberty. 30 October. Publicado em: [http://www.rferl.org/content/ Turkeys_Kissinger_Leads_ForeignPolicy_Balancing_Act/1865343.html]. Disponibilidade: 09/11/2009.

EURACTIV. 2009. Turkey Warned over Cyprus Reunification Standstill. 29 October. Publicado em: [http://www.euractiv.com/en/enlargement/turkey-warned-cyprusreunification-standstill/article-186887]. Disponibilidade: 09/11/2009.

EURACTIV. 2009. Turkey's Turkey's Game for the Caucasus. 16 October. Publicado em: [http://www.euractiv.com/en/enlargement/turkey-game-caucasus/article-186438?Ref=RSS]. Disponibilidade: 09/11/2009. 
FERGUSON, R. James. 2007. Turkey's Multi-Regional Perspective. Department of International Relations, FHSS, Bond University, Australia. Publicado em: [http://www.internationalrelations.com/wbeurasia/Turkey-2007.pdf]. Disponibilidade: 10/11/2009.

FERNANDES, José Pedro Teixeira. 2007. A Turquia na União Europeia. Revista Atlântico. 17 November. Publicado em: (http://www.jptfernandes.com/docs/art_opiniao_turquia_ atlantico.pdf). Disponibilidade: 09/11/2009.

KENE, Bülent. 2009. Turkey, Iraq Sign Deals for Regional Integration. Today's Zaman. 16 October. Publicado em: [http://www.todayszaman.com/tz-web/news-190067-turkey-iraqsign-deals-for-regional-integration.html]. Disponibilidade: 09/11/2009.

GOMES, Ana. 2007. Intervenção em Conferência no Instituto de Estudos Estratégicos e Internacionais sobre as relaçóes entre a Europa e a Turquia. 13 November. Publicado em: [http://aba-da-causa.blogspot.com/2007/11/interveno-em-conferncia-no-ieei-sobre.html]. Disponibilidade: 18/03/2009.

GÜRCANLI, Zeynep. 2008. Turkey to Veto EU's Kosovo Police Mission. Hürriyet, 18 January. Publicado em: [http://www.hurriyet.com.tr/english/8256139.asp? gid=74\&sz=4614]. Disponibilidade: 18/03/2009.

HADDAD, Rim. 2009. Turkey Boosts Syria Ties Amid Renewed Israel Row. 13 October. Publicado em: [http://www.google.com/hostednews/afp/article/ALeqM5jF-osJOu6rD9nmyvmLPPDykdYBg]. Disponibilidade: 09/1103/2009.

LARRABEE, Stephen. 2009. How Turkey is Re-discovering its Middle East Role. Europe's World. Autumn. Publicado em: [http://www.europesworld.org/NewEnglish/Home_old/ Article/tabid/191/ArticleType/articleview/ArticleID/21503/Default.aspx]. Disponibilidade: 12/11/2009.

MILLI GAZETE. 2007. Israel seeks an alliance with Turkey against Iran. 18 February. Publicado em: [http://www.informationclearinghouse.info/article17108.htm]. Disponibilidade: 18/03/2009.

"Military". Publicado em: [http://www.globalsecurity.org/military/world/active-force.htm]. Disponibilidade: 15/10/2009.

ÖZERKAN, Fulya. 2008. Turkey Raises Profile in Long-neglected Middle East. 28 May. Publicado em: [http://english.cri.cn/2947/2008/02/13/1321@322582.htm]. Disponibilidade: 15/10/2009.

POPE, Hugh. 2009. The EU-Turkey-Cyprus Triangle: "Turkey and Armenia Vow to Heal Past Wounds". International Crisis Group, 1 September. Publicado em: [http://www.crisisgroup. org/home/index.cfm?id=6295\&l=1]. Disponibilidade: 06/11/2009.

POPE, Hugh. 2009. Turkey's Rising Star. Council on Foreign Relations. 9 October. Publicado em: [http://www.cfr.org/publication/17462]. Disponibilidade: 09/11/2009.

PRESSTV. 2009. Erdogan Urges World to Recognize Hamas. 1 February. Publicado em: (http://www.presstv.ir/detail.aspx?id=84347\&sectionid=351020202]. Disponibilidade: $09 / 11 / 2009$.

RAMONET, Ignacio. 2004. A Turquia e a vocação europeia. Le Monde Diplomatique. Novembro. Publicado em: [http://diplo.uol.com.br/2004-11,a1013]. Disponibilidade: 06/11/2009.

SCHLEIFER, Yigal. 2009. Turkey: Ankara Pressing Ahead With Diplomatic Make-Over. 04 November. Publicado em: [http://www.eurasianet.org/departments/insightb/articles/ eav110409b.shtml]. Disponibilidade: 06/11/2009. 
THE ECONOMIST. 2009. Looking East and South. 29 October. Publicado em: [http:// www.economist.com/world/middleeast-africa/displaystory.cfm?story_id=14753776]. Disponibilidade: 06/11/2009.

THOMSON REUTERS. 2008. EU's Solana: Turkey incursion “not best response”. 22 February. Publicado em: [http://www.reuters.com/article/topNews/idUSL2247927720080222]. Disponibilidade: 16/10/2009.

USLU, Emrullah. 2009. Erdogan's Visit to Tehran Raises Questions over Turkish Foreign Policy. Eurasia Daily Monitor. Volume 6, Issue 199, 29 October. Publicado em: [http://www. jamestown.org/single/?no_cache=1\&tx_ttnews[tt_news]=35670]. Accessed: 08/11/2009.

Recebido em 13 de novembro de 2009 Aprovado em 18 de janeiro de 2010

\begin{abstract}
This study explores the impact of Turkey's likely entry in the European Union (EU) in terms of the EU's foreign, security and defense policies. It reviews Turkish capabilities, namely its military capabilities, which could provide the EU with valuable defense assets. There are differences related to Turkey's relations with the EU, which have increasingly spilled over into the NATO, hindering the development of cooperation over crisis management operations. The article then delves in the implications of Turkey's strategic geographical location to EU policies. It reviews how far the EU and Turkey may have convergent interests in some of the neighboring regions, especially in the Middle East.
\end{abstract}

\title{
Resumo
}

O presente artigo analisa o impacto da possível adesão da Turquia à União Europeia (UE) em termos da política externa, de segurança e defesa. O artigo começa por analisar as capacidades da Turquia, especialmente as suas capacidades militares e de que forma estas poderiam fornecer à UE os recursos de defesa de que necessita. De seguida, examina as divergências nas relações da Turquia-UE, criando obstáculos ao desenvolvimento da cooperação NATO-UE em matéria de gestão de crises. O artigo avalia ainda as consequências para a UE decorrentes da localização estratégica da Turquia. Analisa-se até que ponto a UE e a Turquia poderão ter interesses convergentes em algumas destas zonas, especialmente no Oriente Médio.

Key-words: Turkey; European Union; European Security and Defense Policy; Islam.

Palavras-chave: Turquia; União Europeia; Política de Segurança e Defesa; Islã. 